\author{
R. Hand, C. S. Christodoulou, A. Kyratzis, G. Chrysostomou \& E. M. \\ McLoughlin
}

\title{
Rostraria hadjikyriakou (Poaceae), a new gypsophilous and endemic species from Cyprus
}

\begin{abstract}
Hand, R., Christodoulou, C. S., Kyratzis, A., Chrysostomou, G. \& McLoughlin, E. M.: Rostraria hadjikyriakou (Poaceae), a new gypsophilous and endemic species from Cyprus. F1. Medit. 31: 71-82. 2021. — ISSN: 1120-4052 printed, 2240-4538 online.

Rostraria hadjikyriakou (Poaceae) is described as new to science. This gypsophilous taxon occurs in three disjunct sites in the eastern half of Cyprus. From a morphological point of view there are similarities to the polymorphic and widespread $R$. cristata. However, it differs by a number of discontinuous characters from this species as well as all other members of the genus. Provisionally, it can be classified as "Vulnerable".
\end{abstract}

Key words: gypsum, Koeleriinae, micro-endemism, Mediterranean islands.

\section{Introduction}

The genera Koeleria Pers. and Rostraria Trin. are closely related to each other and to Trisetum Pers. (Saarela \& al. 2017). The same authors summarise the systematic history of these genera, which are part of the subtribe Koeleriinae Asch. \& Graebn. Thus, various authors have considered Rostraria to be an annual derivative of the perennial Koeleria, differing also in longer awns. This position has already been adopted by the last and only monograph of the group (Domin 1907). In the $20^{\text {th }}$ century most authors argued in favour of a generic status of Rostraria (initially often sub Lophochloa Rchb.). In all recent phylogenetic studies, sampled species of Koeleria and Rostraria resp. have consistently been resolved as closely related within the Koeleriinae clade (Saarela \& al. 2017). Phylogenetic results are still contradictory as regards various genetic markers. Saarela \& al. (2017) summarised them as follows: "Clarification of generic circumscription of species of Rostraria awaits better taxon sampling of the genus and taxonomic decisions for the whole clade.".

The absolute number of taxa is still controversial. The only monograph of the genus nowadays separated as Rostraria was published more than 100 years ago (Domin 1907) and is outdated. Henderson \& Schäfer (2003) mention "about ten species". Clayton \& al. (2020) accept 13 species, of which most occur in the Euro-Mediterranean region. 
However, there are at least two taxa, $R$. clarkeana (Domin) Holub described from Kashmir and $R$. trachyantha (Phil.) Soreng from $\mathrm{S}$ America, restricted to areas outside this presumable centre of diversification. Phylogeny of the latter seems to be in need for clarification (see results by Persson \& Rydin 2016). Details about morphology, distribution and other aspects can be found in the database by Clayton \& al. (2020) and need not to be listed here.

Concerning Cyprus, the current checklist of the country comprises five species (Hand \& al. 2021). Apart from the common and polymorphic $R$. cristata (L.) Tzvelev, $R$. smyrnacea (Trin.) H. Scholz can be found scattered, however island-wide. $R$. amblyantha (Boiss.) Holub, R. obtusiflora (Boiss.) Holub and R. hispida (Savi) Doğan are rarer, and the latter has not been confirmed in recent decades. The spectrum of taxa has not changed since Bor (in Meikle 1985). In his treatment, all taxa are described in great detail (sub Lophochloa). A modified version of the determination key for the species occurring in Cyprus can be found online (Hand \& al. 2021).

On 5 April 2018, Georgios N. Hadjikyriakou found a Rostraria population SW of Mandres Ammochostou, at the S foothills of the Pentadaktylos range in Cyprus. He and, subsequently, the authors of this contribution failed to identify it with any species of the genus, including the numerous infraspecific taxa of $R$. cristata (see Domin 1907), to which it seems systematically close. Further examination as well as intensive field studies, which also led to additional records in other parts of Cyprus, strongly suggest that these plants represent a taxon new to science.

\section{Material and methods}

Results are based on all-year round studies of all known populations in the field, on the Rostraria gatherings conserved in the herbaria B and CYP as well as in the private herbarium of G. Hadjikyriakou (herb. GeoHad), and plants of the new taxon grown at the Agricultural Research Institute (ARI) at Athalassa, Cyprus.

Taxonomy and nomenclature of taxa occurring in Cyprus follow Hand \& al. (2021). Geographical coordinates refer to the UTM 36N zone.

\section{Results}

Rostraria hadjikyriakou Christodoulou \& Hand, spec. nova

Holotypus: Cyprus, Division 7 (sensu Meikle 1985), Ypsarovounos forest, c. $2.5 \mathrm{~km}$ southwest of Mandres Ammochostou, on somewhat vertical or steep, almost bare and soft gypsum faces of few square metres, with flattish patches on or at their base, alt. c. 280 m, 5.4.2018, G. Hadjikyriakou 7600 (CYP; isotypes ARI, B, G, PAL, STU, herb. GeoHad).

Diagnosis: Rostraria hadjikyriakou differs from other Rostraria taxa, namely the group with unequal glumes by culms never extending beyond the leaf sheaths and by spikelets which do not disarticulate. Furthermore, compared to morphologically similar species, 
it differs from $R$. hispida by, e.g., only 2 fertile florets per spikelet (not 3-4) and by the spikelets which are not longer than $2.5 \mathrm{~mm}$ (not $4-5 \mathrm{~mm}$ ). It differs from $R$. rohlfsii by, e.g., panicles not longer than $2 \mathrm{~cm}$ (not 3-10 $\mathrm{cm}$ ) and also by shorter spikelets (not $2.0-5.5 \mathrm{~cm}$ ). From the highly variable $R$. cristata it differs inter alia by only 2 fertile florets per spikelet (not 3 and more), by ligules not longer than $0.6 \mathrm{~mm}$ (not 1-3 $\mathrm{mm}$ ) and by very short spikelets, which are never longer than $2.5 \mathrm{~mm}$ (only very rarely shorter than $3 \mathrm{~mm}$ in $R$. cristata).

Annual, 2-5 cm tall. Culms usually 1-2, rarely with up to 2 additional fertile or sterile branches, arising from basal or upper nodes, erect, never extending beyond the sheath top, glabrous, green to purplish, shining. Leaf-blades lanceolate or linear-acuminate, flat, somewhat rigid, $10-30 \times 0.8-2.3 \mathrm{~mm}$, covered on both surfaces with sparse or dense, long or short, spreading or ascending hairs, usually those of the upper surface longer than those of the lower, scabrid on the margins; sheaths striate, clasping the culms and parts of the panicle, the uppermost inflated, margins widely membranous, indumentum externally as in leaf-blades; ligule c. $0.4-0.6 \mathrm{~mm}$ long, membranous, truncate, usually lacerate. Panicle very dense, ellipsoid or oblong, sometimes ovoid, rounded or obtuse at the apex, $0.8-2.0(-2.6) \times 0.2-0.8 \mathrm{~cm}$, light green, changing into light brown after anthesis; spikelets (2.0-)2.2-2.5 mm long excluding the awns, laterally compressed, wedge-shaped; florets 5, the lower 2 always bisexual, the upper 3 sterile, reduced to empty lemmas; pedicels $0-0.5 \mathrm{~mm}$; axis glabrous; rachilla not disarticulating above the glumes and below the florets, glabrous; glumes unequal, carinate, the lower 1-nerved, scabrid at the back of the nerve, oblong, $1.2-1.8 \times 0.2-0.3 \mathrm{~mm}$, subulate, acute to acuminate, narrowly membranous, the upper glabrous, ovate, 3-nerved, longer than the lower floret, $(2.0-) 2.3-2.5 \times 0.9-1.1 \mathrm{~mm}$, acute, margins broadly membranous; lemmas of the 2 bisexual florets keeled, 5-nerved, somewhat prominent, with dense, spreading or ascending, stiff hairs, margins broadly membranous on the upper part, bifid at the tip, awned in the sinus, each leg of which is acute, restricted chiefly within the membranous margins width; lowest lemma 1.8-2.0(-2.2) $\times 1.0 \mathrm{~mm}$; upper lemmas smaller 1.3-1.5 × 0.8-1.0 mm; awn simple, straight, not articulated, (1.0-)2.5-3.5 mm long, scabrid, green to purplish; palea conspicuously shorter and narrower than the lemma, linear, 0.8-1.0 mm long as a whole, 2-nerved, ciliate on the nerves, the nerves excurrent at the tip into two short aristulae; the 3 empty lemmas shortly hairy or subglabrous, $1.0-1.5 \mathrm{~mm}$ long, the lowest one bifid, mucronate or with a usually short, $0.3-0.5(-2.3) \mathrm{mm}$ long awn in the sinus, the other 2 cuculate, obtuse or rounded, not awned, all 3 forming an obovate structure, c. $1.5 \mathrm{~mm}$ long, rounded on top. Ovary without a hairy apical appendage. Anthers 3, ellipsoid to oblong, (0.3-)0.4-0.6 mm long. Caryopsis $1.5-1.7 \times 0.6 \mathrm{~mm}$, oblong, compressed, rounded at both ends, brown.

Illustrations: Fig. 1-3; see also photo documentation in Hand \& al. (2021).

Phenology: Flowering March-April.

Etymology: The new species is dedicated to Georgios N. Hadjikyriakou (Trachoni Lemesou) on the occasion of his $75^{\text {th }}$ birthday $(* 18.8 .1946)$ who not only discovered 


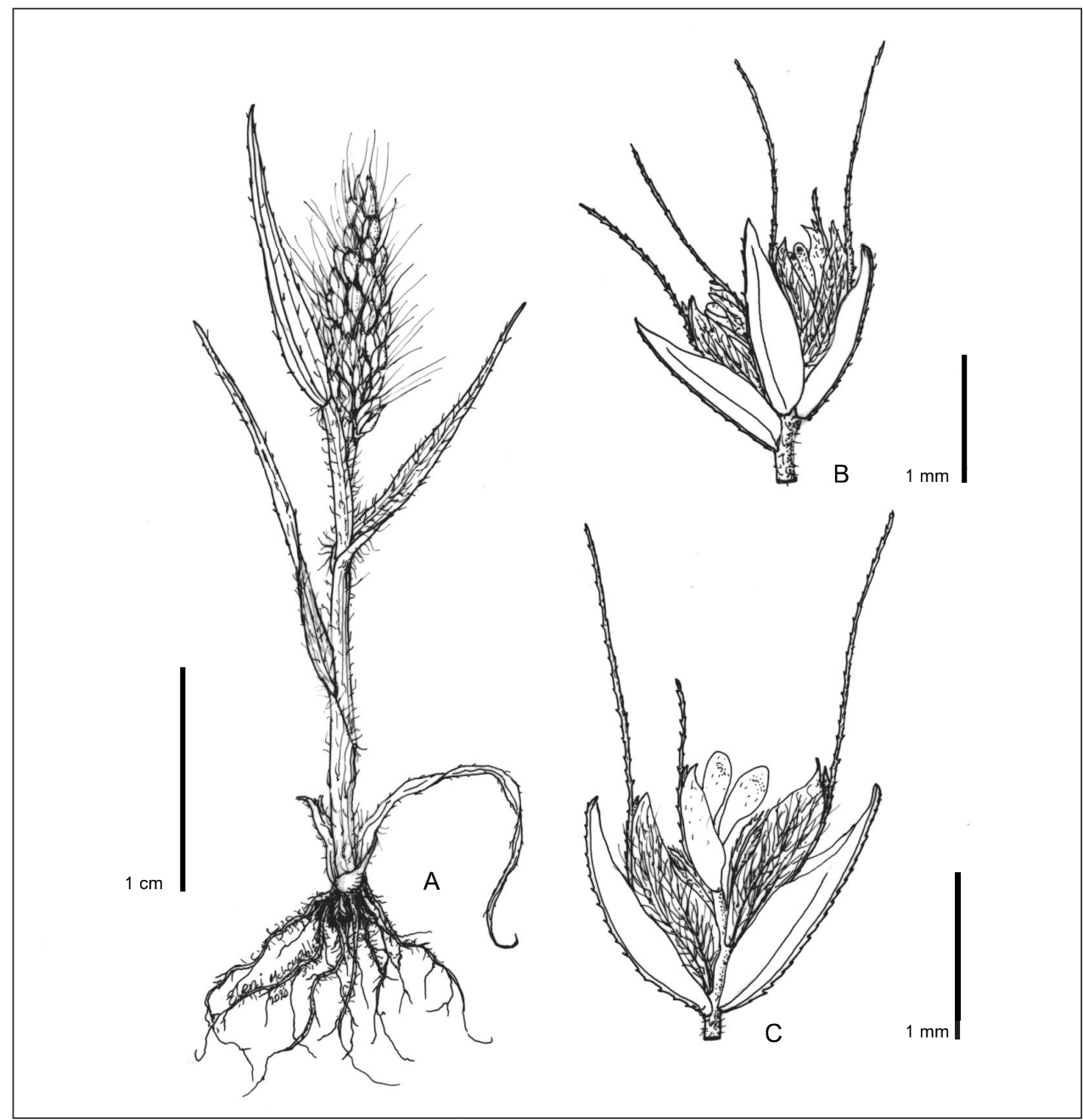

Fig. 1. Rostraria hadjikyriakou: A) habit; B) Two spikelets; C) spikelet with spread flower components; based on the specimen Agios Iakovos, Ypsarovounos, alt. 277 m, 4.4.2019, R. Hand 9271 \& G. Hadjikyriakou (CYP). - Drawings: E. M. McLoughlin.

the plant in the field but also provided us with his detailed results of his studies and accompanied us in various excursions to the gypsum sites of Cyprus. His Greek family name is already in genitive form and is here apposed to the generic name as an indeclinable epithet.

Specimens seen (all known gatherings of $R$. hadjikyriakou and selected specimens of three morphologically similar Rostraria taxa used for comparison, phytogeographical divisions in Cyprus sensu Meikle 1985): 


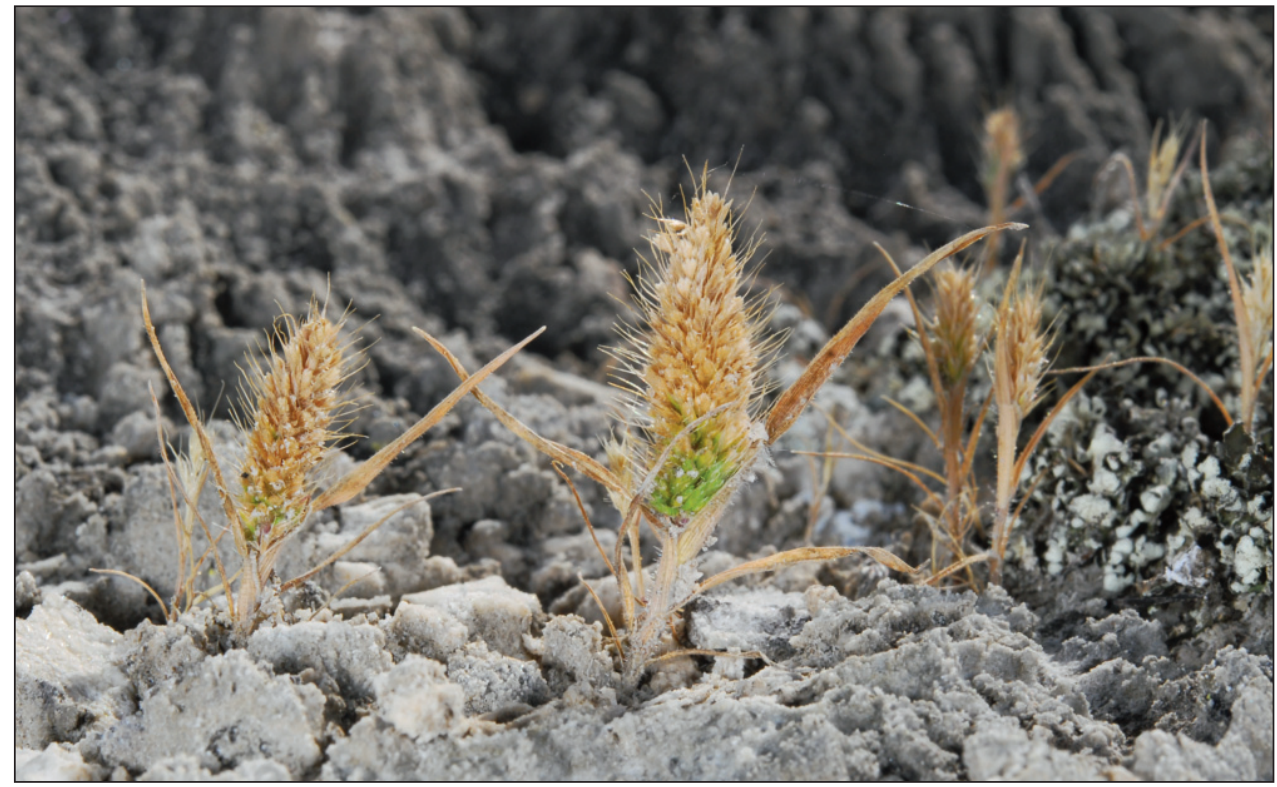

Fig. 2. Rostraria hadjikyriakou, fruiting plants in typical micro-habitat, Cyprus, Ypsarovounos, 14 April 2018. - Photo: C. S. Christodoulou.

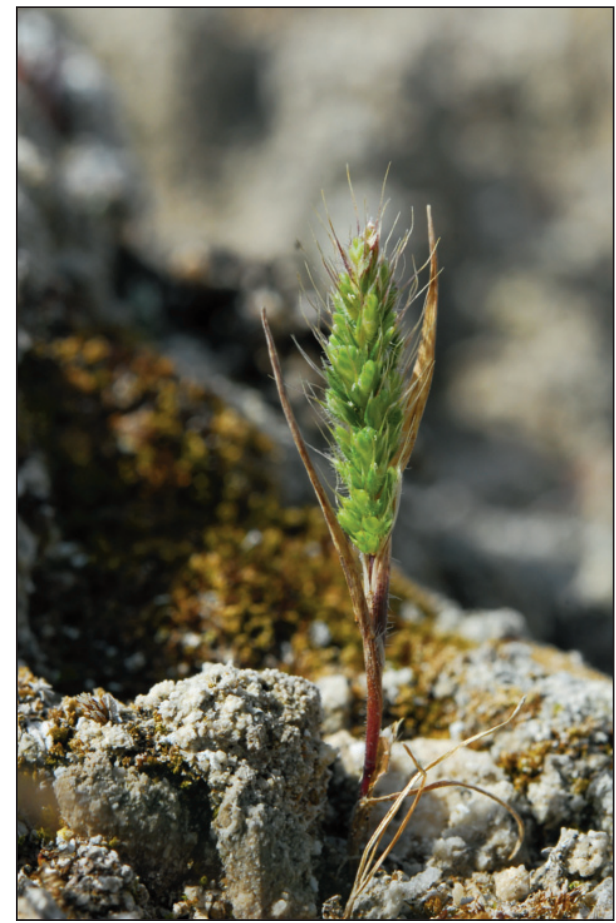

Fig. 3. Rostraria hadjikyriakou, habit, Cyprus, Ypsarovounos, 14 April 2018. - Photo: C. S. Christodoulou. 


\section{R. hadjikyriakou}

Cyprus: Division 3, Between Tochni and Kalavasos c. $1.6 \mathrm{~km}$ to the south, alt. $125 \mathrm{~m}$, 30.5.2020, G. Chrysostomou (B, CYP 6586); ibid., on undisturbed gypsum outcrops with very sparse phrygana, 18.6.2020, C.S. Christodoulou, G. Chrysostomou \& K. Iosif (B, CYP 6587). - Division 7, Ypsarovounos forest, c. $2.5 \mathrm{~km}$ southwest of Mandres Ammochostou, alt. c. $280 \mathrm{~m}, 8.8 .2018$, G. Hadjikyriakou 7625 (herb. GeoHad); ibid., 9.9.2018, G. Hadjikyriakou 7631 (herb. GeoHad); Agios Iakovos, Ypsarovounos, central part, open gypsum slopes, but only on small banks with fine, soft material, not on hard gypsum rocks, alt. 277 m, 19.6.2018, R. Hand 9029 \& G. Hadjikyriakou (B); ibid., 4.4.2019, R. Hand 9271 \& G. Hadjikyriakou (CYP). - Division 8, 2 km southeast of Agios Symeon, Karpasia peninsula, alt. c. 70-90 m, 28.4.2018, G. Hadjikyriakou 7613 (herb. GeoHad).

\section{R. cristata}

Cyprus: Division 1, Pafos, near the lighthouse, rocky beach, alt. c. 3 m, 1.4.1998, R. Hand 2045 (B). - Division 2, Agios Ioannis, SW slope of mountain SE of the village, phrygana on abandoned vineyards, alt. c. 800 m, 4.5.1999, R. Hand 3070 (B). - Division 3, Kofinou, alt. c. 250 m, 20.4.1998, G. Hadjikyriakou 3152 (herb. GeoHad); east of Akrotiri Salt Lake, alt. 0 m, 9.4.1999, G. Hadjikyriakou 4278 (herb. GeoHad); Zakaki-Akrotiri Salt Lake, alt. 0 m, 9.4.1999, G. Hadjikyriakou 4285 (herb. GeoHad); Mazotos, Akro Petounta, W of cape and W of bifurcation of tracks, sandy margins by track along rocky plateau, alt. 10 m, 30.3.2019, R. Hand 9241 (CYP). - Division 4, South Larnaka Salt Lake, alt. c. 0 m, 12.4.1999, G. Hadjikyriakou 4333 (herb. GeoHad); ibid., 12.4.1999, G. Hadjikyriakou 4334 (herb. GeoHad); Ormideia, alt. 30 m, 17.4.1999, G. Hadjikyriakou 4388 (herb. GeoHad); Perivolia, c. $600 \mathrm{~m} \mathrm{~W}$ of lighthouse, $\mathrm{S}$ of Archiepiskopou Makariou III, sandy beach, alt. 2 m, 31.3.2019, R. Hand 9250 (CYP). - Division 8, Moni Apostolou Andrea, c. $800 \mathrm{~m} \mathrm{~W}$ Kastros, at coastal track, rocky and sandy beach, alt. c. 5 m, 29.4.2005, R. Hand 4750 \& G. Hadjikyriakou (B).

\section{R. hispida}

Greece: ins. Kos (Dodekanes), östl. Marmari bei den Salinen im Salzrasen, 26.4.1990, H. Scholz (B).

Italy: Palermo, in argillosis hyeme inundatis, s. d., ex. herb. R. Gross (B).

Tunisia: Salzsteppe am Meer zwischen Enfidaville u. Sebkrat, 16.4.1968, Assa Djiriba [eligible] \& H. Scholz (B).

\section{R. rohlfsii}

Libya: Fezzan, Wadi esc Sciati, Brak: campi coltivati a E del paese fra la strada e l'altipiano, 28.2.1978, C. Ricceri \& C. H. Steinberg, conf. H. Scholz (B); Fezzan, Sebha, ruderal an bewässerten Gräben der Stadt, 8.4.1970, H. Scholz (B); Tripolitanien, Tripolis, in der Stadt, 3.4.1970, H. Scholz (B).

Algeria: Oase Oued Said an d. Sebka v. Timimoun, stark versandet, Nähe d. Faggara, 27.2.1978, Schmidt, det. H. Scholz (B); El Goleà, in hortis, 4.1904, L. Chevallier (B); Metlili, El Goleà, in cultis, 6.-13.3.1899, L. Chevallier (B).

Tunisia: gouvern. de Mededine, île de Jerba, Houmt Souk (côte nord), terrain rudéral..., 7.4.1999, J. Lambinon 99/Tu/24 \& J. Margot (B). 


\section{Distribution and ecology}

R. hadjikyriakou was first located at Ypsarovounos forest (ýpsaros = gypsum + vounón = mountain), in the vicinity of Mandres, Agios Iakovos and Platani villages (main occurrence at $572184 \mathrm{E} 3909366 \mathrm{~N}$ ). More specifically it was located $2.5 \mathrm{~km} \mathrm{SW}$ of Mandres Ammochostou (c. 2000 plants) and at Kakotris gypsum hill (c. 20 plants), $1 \mathrm{~km} \mathrm{~S}$ of the same village (division 7, sensu Meikle 1985). Further investigations were carried out in division 8 but the new species was found only $2 \mathrm{~km}$ E of Agios Symeon village (Karpasia peninsula), about $45 \mathrm{~km} \mathrm{E}$ of the type locality. In an area of about one hectare (co-ordinates 612203 E $3926980 \mathrm{~N}$ ) with scattered spots which possess the ecological requirements (see below) 20-30 plants were found growing here and there in groups of 2-5. Finally, in May 2020 the species was discovered $2.2 \mathrm{~km} \mathrm{SW}$ of Tochni village (500-1000 plants; coordinates 592022 E $3846652 \mathrm{~N}$ ), growing on undisturbed gypsum outcrops along with other typical gypsophiles (see Fig. 4).

A search, without any success, has also been performed in various other gypsum areas of Cyprus by G. Hadjikyriakou and the authors in a very promising region situated between the villages Bogazi and Gastria, about $15 \mathrm{~km}$ E of the type locality (co-ordinates 597964 E $3911280 \mathrm{~N}$ and 590366 E 3911944 N) as well as the poor in gypsophiles, westernmost part of gypsum formations in Pafos district.

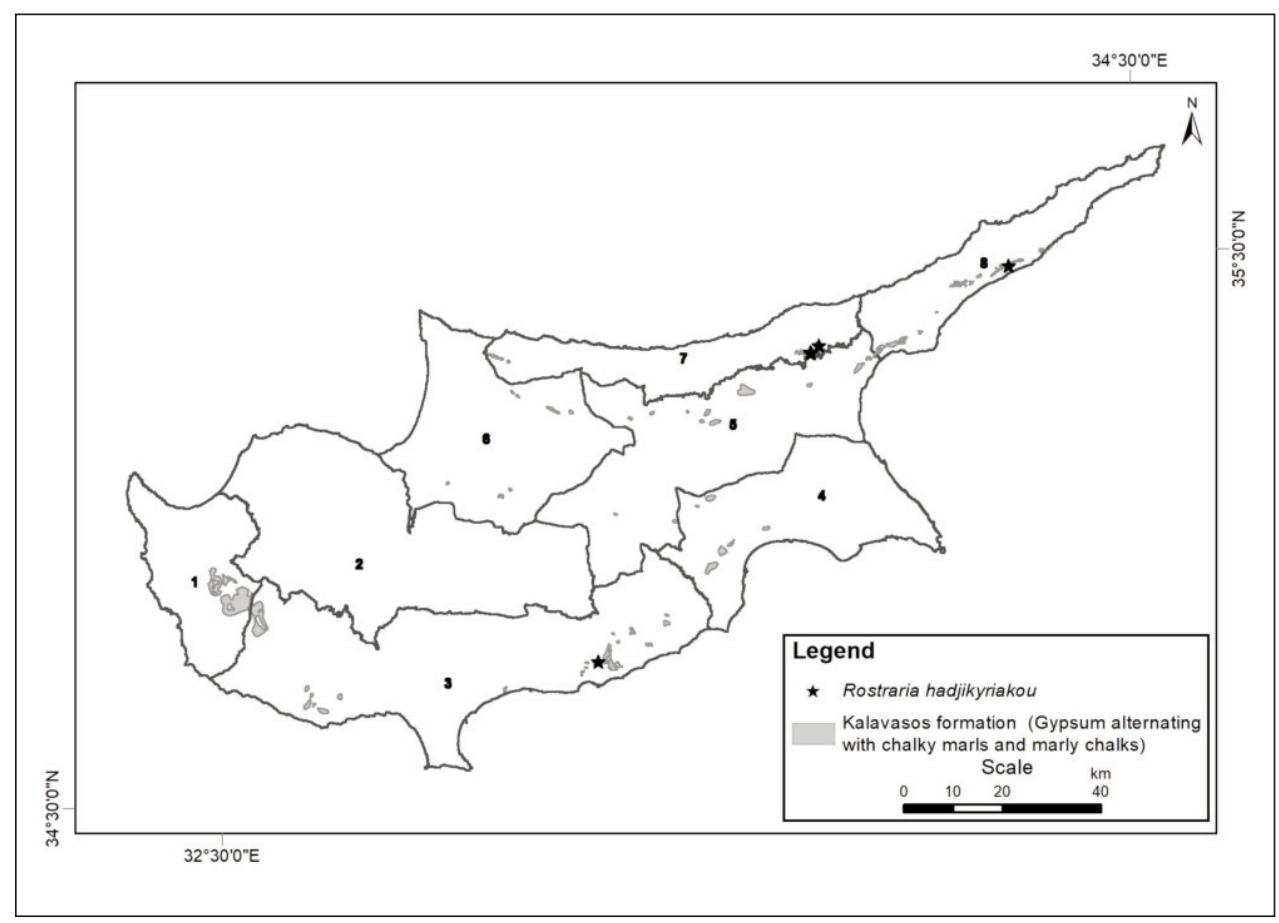

Fig. 4. Rostraria hadjikyriakou, distribution in Cyprus; phytogeographical divisions sensu Meikle 1977, 1985. - Map design: K. Papasavvas. 
During the search it has been observed that $R$. hadjikyriakou usually grows on spots with somewhat vertical or steep, almost bare and soft gypsum faces of few square metres, with flattish patches on or at their base, generally with a low cover of vegetation consisting mostly of therophytes. Hardish gypsum substrate is clearly avoided and is considered a limiting factor (see also Escudero \& al. 2015). The type locality is a compact gypsum outcrop of about $5 \mathrm{~km}^{2}$ with an altitude ranging between 230-300 m a.s.1., whereas the localities at Agios Symeon (between 70-90 $\mathrm{m}$ a.s.1.) and Tochni (110-130 $\mathrm{m}$ a.s.1.) consist of smaller and more fragmented gypsum outcrops. All areas in division 7 are dissected by small streams, and are characterised by steep to even slopes, cliffs and scattered, small flattish areas, whereas in division 3 (Tochni) the site is relatively flat with small, even slopes. Geologically they fall within Kalavasos formation (Upper Miocene), which is composed of gypsum alternating with chalky marls and marly chalks (Geological Survey Department 1995).

Derived from measurements at nearby meteorological stations, precipitation rates of about 400-515 mm per year seem probable, if one considers the special topographical situations (Department of Meteorology 2019).

The habitats colonised belong generally to Gypsum steppes "habitat type 1520" (sensu Annex I of the EU Directive 92/43/EEC), the protection of which is of priority. Trees growing in the vicinity of the known localities are Ceratonia siliqua L., Cupressus sempervirens L., Pinus brutia Ten. and Pistacia lentiscus L., but $R$. hadjikyriakou avoids shade of trees and shrubs. It most often flourishes on bare gypsum slopes and flattish areas or large openings; sometimes it can be found in the shade of dwarf shrubs. Typical accompanying species are Allium cupani subsp. cyprium Meikle, Brachypodium distachyon (L.) P. Beauv., Bromus rubens L., Bupleurum sintenisii Huter, Centaurium pulchellum (Sw.) Druce, Chaenorrhinum rubrifolium (DC.) Fourr., Cheilanthes acrostica (Balb.) Tod., Crepis foetida L., Crupina crupinastrum (Moris) Vis., Erodium crassifolium L'Hér., Filago eriosphaera (Boiss. \& Heldr.) Chrtek \& Holub, Fumana thymifolia (L.) Verl., Minuartia picta (Sm.) Bornm., Onobrychis venosa (Desf.) Desv., Plantago afra L., Psilurus incurvus (Gouan) Schinz \& Thell., Sedum eriocarpum subsp. porphyreum (Kotschy) 't Hart, Teucrium micropodioides Rouy, Thymbra capitata (L.) Cav., Valantia hispida L. (with high frequency) and Vulpia ciliata Dumort. The gypsophilous taxa Campanula fastigiata Schult., Gypsophila linerarifolia (Fisch. \& C. A. Mey.) Boiss. and Teucrium salaminium Hadjik. \& Hand as well as the gypsocline species Herniaria hemistemon J. Gay were also found in close vicinity. At least at the type locality, in a few spots $R$. cristata has been observed growing syntopically with $R$. hadjikyriakou, but there were no indications of intermediacy or interbreeding. However, the latter colonises only gypsum substrate. Hence, it is the second Cypriot gypsophilous endemic, after $T$. salaminium, which was discovered and described from the same type locality.

Field observations showed that, in contrast to other taxa of its genus, in $R$. hadjikyriakou infructescences do not disarticulate nor shed spikelets and remain on the culms up to six months or even more. Spikelets persist during the whole Mediterranean summer until the first autumn rains start. Repeatedly, we found groups of plants which have germinated and grown up from the remains of a mother plant. Such a strategy may be successful in minimising transfer of diaspores to less appropriate micro-habitats within the gypsum coenoses. 


\section{Conservation}

R. hadjikyriakou seems to be a rare endemic of Cyprus and according to the IUCN Red List Categories and Criteria (Version 3.1; IUCN Standards and Petitions Subcommittee (2014) it can provisionally be characterised as VU (Vulnerable): D2. This means that the area of occupancy is less than $20 \mathrm{~km}^{2}$ and the number of locations are less than five, concretely three. Potential threats are grazing, quarrying of gypsum, road construction, agriculture and forestry operations. There are two main subpopulations, the largest one is found at Ypsarovounos, which is State Forest Land and the second and smaller one at Tochni area. At both locations, the species is part of the priority habitat Gypsum steppes $(1520 *)$.

Seeds from the Ypsarovounos region (leg. G. Hadjikyriakou, 2018) are stored under the accession number ARI02418 in the Agricultural Research Institute (Athalassa).

\section{Discussion}

Material of the new taxon has been compared to all known Rostraria species. The cultivation of plants under standardised conditions revealed that all relevant morphological characters observed in the field and in herbarium material are constant and not influenced by ecological factors. Plants showed only a slightly more vigorous growth. $R$. hadjikyriakou belongs to the group of species which possess unequal glumes. However, it displays a unique combination of characters which has not been documented for any other Rostraria taxon. Its culms are always enclosed in the subtending leaf sheaths. After anthesis the infructescences do not disarticulate and persist for various months whereas in other Rostraria taxa a quick disarticulation can be observed. Furthermore, spikelets of $R$. hadjikyriakou always develop two fertile florets as opposed to three and more in the congeneric taxa. From a morphological point of view, three taxa from this group show certain affinities and were included in a closer comparison. Differences to $R$. hispida and $R$. rohlfsii have been summarised in the diagnosis. Details in comparison are outlined in Table 1 . The widespread and very polymorphic $R$. cristata has many similarities to $R$. hadjikyriakou but differs by various characters (see also diagnosis and Tab. 1). In Cyprus as well as in the vast majority of regions elsewhere in the Mediterranean, $R$. cristata develops spikelets longer than $3 \mathrm{~mm}$, often considerably so, whereas $R$. hadjikyriakou is characterised by more delicate spikelets not longer than $2.5 \mathrm{~mm}$. However, two infraspecific taxa of the former with exceptionally small spikelets demand a closer look. Both of which have been described by Domin (1907): Koeleria phleoides var. azorensis from the Azores islands and K. phleoides var. nitens from S Italy. In both, exceptionally small spikelets (minimum length c. $2 \mathrm{~mm}$ ) have been documented. The latter variety differs not only in the general characters unique for $R$. hadjikyriakou, but also in (sub)glabrous, whitish spikelets and the lax, lobate panicle. The former variety is said to have three flowers of which - according to the illustration by Domin (1907) - only the lowest one is shortly awned. Among other characters described, the golden-coloured panicles may be mentioned. Henderson \& Schäfer (2003) revised original material of this taxon. They concluded that in this and other material from the Azores "variation is neither distinct nor consistent enough to warrant varietal status". 
Table 1. Main differences of Rostraria hadjikyriakou in comparison with selected Rostraria taxa, diagnostic characters in bold and shades of grey; main sources: Domin (1907); Clayton \& al. (2020), supplemented by own measurements and data from Meikle (1985) and Henderson \& Schäfer (2003).

\begin{tabular}{|c|c|c|c|c|}
\hline & R. hadjikyriakou & R. cristata & R. hispida & R. rohlfsii \\
\hline culm length $(\mathrm{cm})$ & $2-5$ & $(2-) 5-45(-70)$ & $5-30$ & $15-30(-35)$ \\
\hline $\begin{array}{l}\text { culm, relation to } \\
\text { sheath }\end{array}$ & $\begin{array}{l}\text { always included in } \\
\text { subtending sheath }\end{array}$ & extending sheath & extending sheath & extending sheath \\
\hline ligule length (mm) & $0.4-0.6$ & $1-3$ & $0.5-0.9$ & $0.5-1$ \\
\hline $\begin{array}{l}\text { leaf-blade upper } \\
\text { surface }\end{array}$ & pilose to pubescent & glabrous to pubescent & pilose & pubescent \\
\hline panicle length $(\mathrm{cm})$ & $0.8-2.0$ & $(0.5-) 1-15(-20)$ & $1-6$ & $3-10$ \\
\hline $\begin{array}{l}\text { number of fertile } \\
\text { florets per spikelet }\end{array}$ & 2 & $3-8(-13)$ & $3-4$ & $2-4$ \\
\hline spikelet length $(\mathrm{mm})$ & $(2.0-) 2.2-2.5$ & $(2-) 3-7(-8)$ & $4-5$ & $4-5.5$ \\
\hline $\begin{array}{l}\text { disarticulation of } \\
\text { spikelet }\end{array}$ & $\begin{array}{c}\text { not breaking up at } \\
\text { maturity, no } \\
\text { disarticulation below } \\
\text { each fertile floret } \\
\end{array}$ & $\begin{array}{c}\text { breaking up at } \\
\text { maturity, } \\
\text { disarticulating below } \\
\text { each fertile floret }\end{array}$ & $\begin{array}{c}\text { breaking up at } \\
\text { maturity, } \\
\text { disarticulating below } \\
\text { each fertile floret }\end{array}$ & $\begin{array}{c}\text { breaking up at } \\
\text { maturity, } \\
\text { disarticulating below } \\
\text { each fertile floret }\end{array}$ \\
\hline $\begin{array}{l}\text { lower glume length } \\
(\mathrm{mm})\end{array}$ & $1.2-1.8$ & $(1.5-) 2-3(-4)$ & $2-5$ & $3-3.5$ \\
\hline upper glume (mm) & $(2.0-) 2.3-2.5$ & $(2-) 3-4(-5.5)$ & $3-4$ & $4-5$ \\
\hline $\begin{array}{l}\text { fertile lemma length } \\
(\mathrm{mm})\end{array}$ & $1.3-2.0(-2.2)$ & $(1.5-) 3-4(-5)$ & $3-4$ & $3-4$ \\
\hline $\begin{array}{l}\text { lemma awn length } \\
(\mathrm{mm})\end{array}$ & $1.0-3.5$ & $0-3$ & $3-5$ & $1-3$ \\
\hline lemma awn position & apically (in the sinus) & $\begin{array}{c}\text { apically (in the sinus) } \\
\text { or subapically }\end{array}$ & subapically & dorsally \\
\hline anther length (mm) & $0.3-0.6$ & $(0.2-) 0.3-0.6$ & $0.7-1$ & $0.5-0.7$ \\
\hline
\end{tabular}

$R$. cristata, also the lectotype of the genus, is a taxon with different ploidy levels and discordant placements in phylogenetic trees. It, or at least some of its cytotypes, may have a putative hybrid origin, which needs clarification (Saarela \& al. 2017). Generally, phylogenetic studies in all known Rostraria species plus various samplings from widespread and variable taxa such as $R$. cristata and the new species from Cyprus would be useful to disentangle the systematics of the genus.

Gypsum ecosystems have been in the focus of nature conservation because of their priority status given by the EU directive. In Cyprus, there have been some intensive studies and monitoring activities within the last 15 years. Therefore, the discovery of a new gypsum endemic comes as a surprise. However, it should be kept in mind that all gypsum specific taxa of the island have been discovered only after the finalisation of the project "Flora of Cyprus" (Meikle 1977, 1985): Campanula fastigiata (Hand 2009), Gypsophila linearifolia (Hand 2006), Herniaria hemistemon (Hand 2006) and the endemic Teucrium salaminium (Hadjikyriakou \& Hand 2011). It is difficult to explain why all of them escaped the attention of previous generations of field-botanists in Cyprus. The newly described taxon $R$. hadjikyriakou is another addition to the list of obligate gypsum sub- 
strate colonisers. The disjunctions within its distribution range are typical for all mentioned taxa. The currently known distribution pattern also confirms that the obligate gypsicolous taxa are restricted to the $\mathrm{S}$ and $\mathrm{E}$ of the island where precipitation is lower compared to the W part. $R$. hadjikyriakou extends the list of taxa that hopefully will boost protection strategies for gypsum ecosystems in Cyprus.

\section{Acknowledgements}

Ioannis Vigiatzakis (Lefkosia) improved a previous draft of the text linguistically. Konstantinos Papasavvas (Lefkosia) kindly helped in the preparation of the distribution map. The Department of Meteorology (Lefkosia) provided us with unpublished meteorological data. We would like to thank GYPWORLD project (funded by the EU Horizon 2020 Programme/MSCARISE-2017 Grant Agreement n. 777803) for instigating further research on the gypsum communities in Cyprus through the research work undertaken by Georgia Chrysostomou. Nick Turland (Berlin) thankfully provided nomenclatural advice. Last, but not least the authors thank Georgios N. Hadjikyriakou (Trachoni Lemesou, Cyprus) who enabled our studies on the newly discovered taxon.

\section{References}

Bor, N. L. 1985: 28. Lophochloa Reichb. Pp. 1766-1770 in: Meikle, R. D. (ed.), Flora of Cyprus, 2. - Kew.

Clayton, W. D., Vorontsova, M. S., Harman, K. T. \& Williamson, H. 2020: GrassBase - The Online World Grass Flora. - http://www.kew.org/data/grasses-db.html [Last accessed 21.7.2020]

Department of Meteorology 2019: Station 572, Kalavasos, Climatological data 1989-2018. Lefkosia.

Domin, K. 1907: Monographie der Gattung Koeleria. - Biblioth. Bot. 65.

Escudero, A., Palacio, S., Maestre, F. T. \& Luzuriaga, A. L. 2015: Plant life on gypsum: a review of its multiple facets. - Biol. Rev. Cambridge Philos. Soc. 90: 1-18. https://doi.org/ 10.1111/brv. 12092

Geological Survey Department 1995: Geological map of Cyprus. Revised Edition. - Lefkosia.

Hadjikyriakou, G. \& Hand, R. 2011: Teucrium salaminium (Lamiaceae, Teucrium sect. Polium), a new species from Cyprus. - Candollea 66: 341-351. https://doi.org/10.15553/c2011v662a11

Hand, R. (ed.) 2006: Supplementary notes to the flora of Cyprus V. - Willdenowia 36: 761-809. https://doi.org/10.3372/wi.36.36211

- (ed.) 2009: Supplementary notes to the flora of Cyprus VI. - Willdenowia 39: 301-325. https://doi.org/10.3372/wi.39.39209

—, Hadjikyriakou, G. N. \& Christodoulou, C. S. (eds) 2021 (continuously updated): Flora of Cyprus - a dynamic checklist. - http://www.flora-of-cyprus.eu/ [Last accessed 10.5.2021]

Henderson, S. \& Schäfer, H. 2003: Synopsis of the genus Rostraria (Poaceae) in the Azores. - Bot. J. Linn. Soc. 141: 125-131. https://doi.org/10.1046/j.1095-8339.2003.00114.x

IUCN Standards and Petitions Subcommittee 2014: Guidelines for Using the IUCN Red List Categories and Criteria. Version 11. Prepared by the Standards and Petitions Subcommittee. http://www.iucnredlist.org/documents/RedListGuidelines.pdf [Last accessed 21.7.2020].

Meikle, R. D. 1977, 1985: Flora of Cyprus, 1-2. - Kew.

Persson, N. L. \& Rydin, C. 2016: Phylogenetic relationships of the 'Briza complex' to other members of the subfamily Pooideae (Poaceae). - Pl. Ecol. Evol. 149: 216-227. http://dx.doi.org/10.5091/plecevo.2016.1194 
Saarela, J. M., Bull, R. D., Paradis, M. J., Ebata, S. N., Peterson, P. M., Soreng, R. J. \& Paszko, B. 2017: Molecular phylogenies of cool-season grasses in the subtribes Agrostidinae, Anthoxanthinae, Aveninae, Brizinae, Calothecinae, Koeleriinae and Phalaridinae (Poaceae, Pooideae, Poeae, Poeae chloroplast group 1). - PhytoKeys 87: 1-139. https://doi.org/ 10.3897/phytokeys.87.12774

Addresses of the authors:

Ralf Hand ${ }^{1}$, Charalambos S. Christodoulou ${ }^{2}$, Angelos Kyratzis ${ }^{3}$, Georgia Chrysostomou $^{2}$ \& Eleni M. McLoughlin ${ }^{4}$,

${ }^{1}$ Winterfeldtstr. 25, D-10781 Berlin, Germany. E-mail: ralfhand@gmx.de

${ }^{2}$ Department of Forests, Ministry of Agriculture, Rural Development and Environment, 26 Louki Akrita street, CY-1414 Lefkosia, Cyprus. E-mails: cyflora@outlook.com,geo_chrysostomou@hotmail.com

${ }^{3}$ Agricultural Research Institute, Ministry of Agriculture, Rural Development and Environment, P. O. BOX 22016, P .C., CY-1516 Athalassa, Cyprus; E-mail: a.kyratzis@ari.gov.cy

${ }^{4} 12$ Wenlock Close, Mickleover, Derby, DE3 9NT, U.K. E-mail: em44uk@gmail.com 